\title{
The dynamothermal aureole of the Donqiao ophiolite (northern Tibet)
}

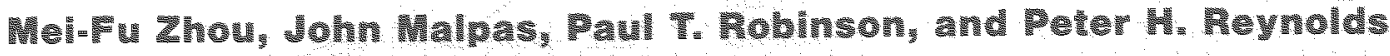

\begin{abstract}
A bstract: Metrmorphic rock found at the base of the Jurassic Donqiao opholite of norhern wbet are interpreted as a basal dynamothermal aurede produced dumg obducton of the massif. The rocks fom a sequence some $8 \mathrm{~m}$ thick, varying from high-grade amphobites at he contae with ovenying harburgtes to greanschist faches netasedimentary rocks lower down. The mineral paragenesis is similar to other such aureoles, and indicates that temperatures in excess of $750^{\circ} \mathrm{C}$ may have been reached dung metamomhin. The lack of high-pressure minerals suggests that the rocks Were produced by subcrenon in a relatively shallow dipping subduction zone. Ar-Ar geochronology on amphibole separates provides dates of $175-180 \mathrm{Ma}$ for the displacement of the opholite, signincanty older than the age of emplacement estmated from stratigraphic relationships. The opholie was cleary obducted very soon after tormation in a suprasubduction zone ervironment.
\end{abstract}

Résumé : Les roches métanomhiques trouvées a la base de lophiolite de Donqua dage Jurassique, dans le Tibet septentrional, sont interprétées comme une auréle dynanothemique basale produte durant lobduction du masstat Les roches forment une sçuence de quelque $8 \mathrm{~m}$ d'epaisseur, variall damphibolites de degré elevé au contact des harzburgites sus-jacentes, et plus bas à des roches métasedimentaires de facièstes schistes yerts. La paragenese des minéraux est simílaire à celle de dautres aureoles, et elle indoue gue les températures au-dessus de $750^{\circ} \mathrm{C}$ on pu etre atteintes durant le métanomhisme. L'absence de nouveam minéraux de pression elevé suggère que les roches furent engendres par une subcretion dans une zone de subduction au a plongé à une profondeur relativement able. La géchronologie Ar-Ar sur des concentres damphibole toumit les dates de $175-180$ Ma pour le deplacernen de

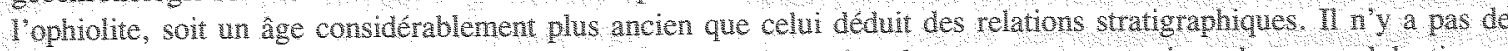
doute que l'ophiolite fut obducté pell de temps apres sa formation dans whe zone tectonique de suprasubducton.

Traduit par la redaction

\section{Iniroduction}

Motamotphic rocks found beneath the mantle perdotites of We Donclao opholite of Tibetare considened to represent a Hnamohermal aueole produced durng intral displacenent doceant litosphere and its obduction onto the conthental Wartun of the Quantang terrane in the Mesozolc (cf. Mapas et al. 1973: Coleman 1977; Malpas 1979, Jameson 1980). We have underiken a sudy of hese rocks to detemine their frutions of fomation and their age. Hero, we descrbe the peroloy and mineralogy of the metamompho rocks, present tew commositional data from the mineral phases, and report

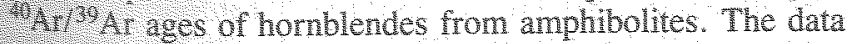
mixy be usd ro model the origin of the aureole and piace conWints on he tectoric evolution of the region.

\section{Oohiolltic dynamothermal aureoles}

The "wbutton" of ophioites and their incomporation into Muntin bols is a complex tectonic process; which can

Tecolved Docember 29, 1995 . Accepted September $11,1996$.

W. f. Zhou and Malmas. Department of Earth Sciences, Wiversity of Hong Kong, Hong. Kong.

11. Wowinson. Centre tor Marine Geology, Dahousie

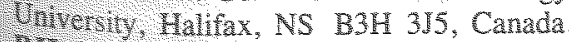

11. Reverdes Deparment of Earh Sciences, Dahousie

Whivethy, Halfax, NS B3H 35, Canda.

Cortevonding auhor (emal: jgmalpasohkucchk.hk). broadly be divided into two stages (Malpas and Stevens 1977 ). The first stage involves the "displacement" of oceanic crust and upper mantle by subduction and underthrusting of oceanic lithosphere and the second, the "emplacement" of the opholite thrust slices onto continental margins, usually accompanied by some form of gravitational sliding and mélange formation. In some ophiolite complexes, especially anong those that are well preserved and that are complete sections of the crust and upper mantle, it is not uncommon to find metamorphic rocks associated with the mantle perdotites. Previously described occurrences include those in Spain (Dickey 1970), southwest England (D.H, Green 1964), Serbia (Karamata 1968), Oman (Searle and Malpas 1980, 1982). Newfoundland (Malpas 1979, Jamieson 1980), and Cyprus (Malpas et al. 1992). At these localities, the metamorphic rocks are best preserved at the base of the ophiolites, or may occur as blocks and knockers in opholitic melange where extensive transport of the thrust slices has dismembered the ophiolite stratigraphy. Commonly referred to as dynamothermal aureoles, the rocks can range in metamorphic grade from granulite facies to subgreenschist facies, and are considered to have been produced during the displacement stage of ophiolite obduction. Based on observations made at locations such as those listed above, a number of criteria have been established that characterize such aureoles (Searle and Malpas 1980):

1. The metamorphic rocks occupy a consistent stratigraphic position at the base of the ophiolite and underlie a thick ultramafic unit. 
Fig. 1. Geological map of the Donqlao ophiolitic massif and cross section of its dynamothermal aureole. LT, Lhasa terrane; QT, Qiangtang terrane.

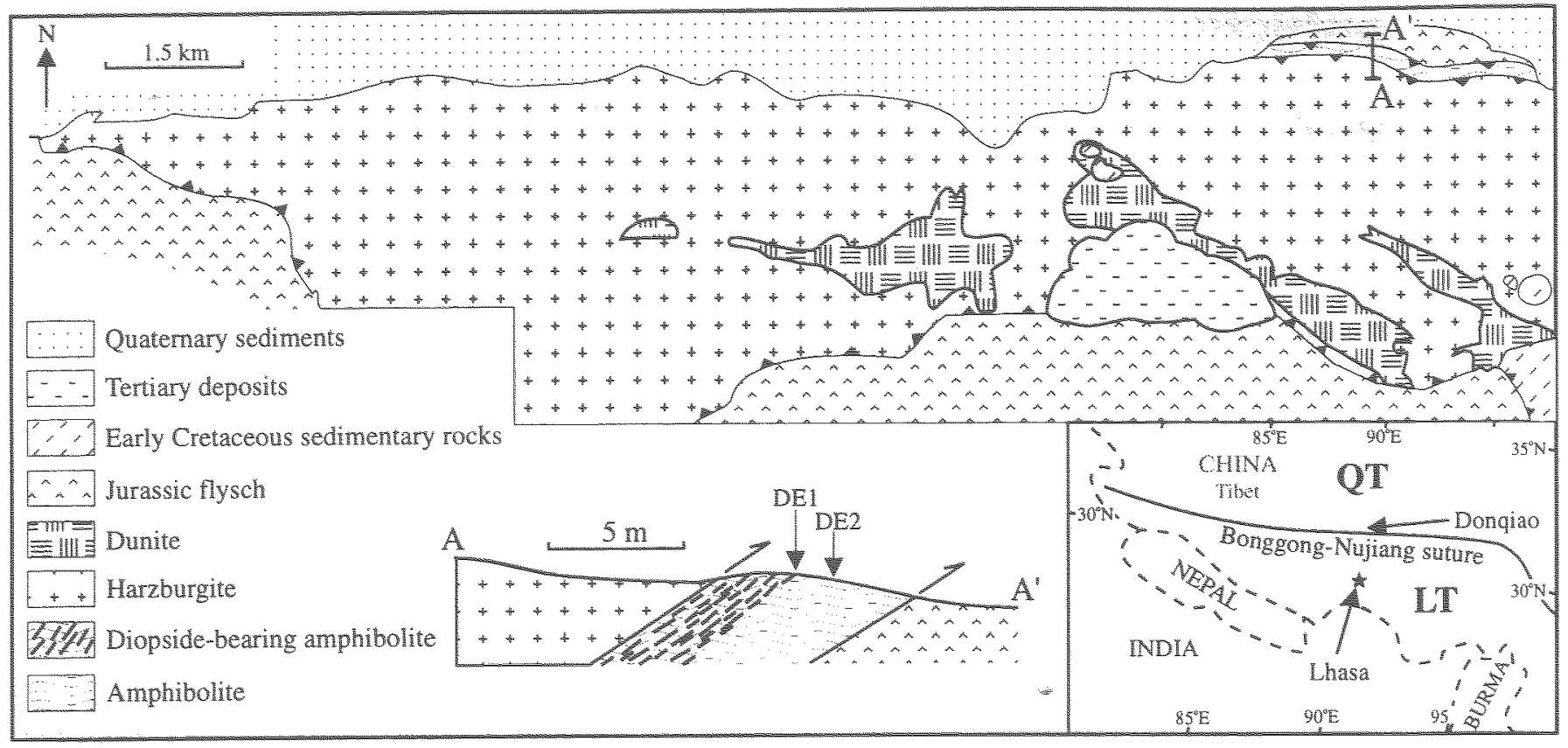

2. There is a general lack of intrusive phenomena (e.g., dykes, xenoliths, chilled margins) associated with the contact between the ultramafic and metamorphic rocks.

3. The metamorphic complexes characteristically have a narrow width, suggesting either a high thermal gradient, and (or) the selective removal of parts of the sequence during thrusting.

4. Where there has been no dismemberment, orientations of the metamorphic fabrics and the conditions of their formation are essentially the same in the basal ultramafic rocks and the metamorphic rocks.

5 . There is rarely any evidence of high-pressure metamorphism in the aureole rocks. Neither jadeite, kyanite glaucophane, or lawsonite are reported and the assumption must be that metamorphism took place at shallow levels, perhaps by subcretion above a shallow-dipping subduction zone.

6. Where best preserved, such as in New foundland or Oman, the metamorphic rocks show an inverted metamorphic zonation from high-grade granuite or upper amphibolite facies immediately beneath the mantle peridotites to subgreenschist facies at lower levels.

Metamorphic rocks in these aureoles are generally polyphase deformed and exhibit mylonitic fabrics in places. Protoliths appear to have been basic igneous rocks, tuffaceous rocks, and a variety of sedimentary rocks, including siltstones, radiolarian cherts, and pelagic limestones. These have been transformed into gametiferous amphibolites, actinolite, chlorite schists, micaceous schists, and marbles. In most cases, the low glaucophane content of the amphiboles (Malpas 1979; Searle and Malpas 1980, 1982; Ghent and Stout 1981; Malpas et al. 1992) and low jadeite composition of clinopyroxenes suggest relatively low pressures of crystallization, particularly in the presence of plagioclase and quartz. This seems a common and, as yet, unexplained feature of ophiolitic dynamothermal aureoles. Temperature estimates obtained from element distribution coefficients in coexisting minerals suggest maxima of the order of $700-800^{\circ} \mathrm{C}$.

The metamorphic rocks of dynamothermal aureoles offer a unique opportunity to place age restraints on the initiation of ophiolite obduction. They are most amenable to ${ }^{40} \mathrm{Ar} /{ }^{39} \mathrm{Ar}$ geochronology, particularly on amphibole separates. Ages so determined have indicated that in many cases, initial ophiolite displacement closely followed the genesis of the oceanic lithosphere at a spreading centre. Residual heat from the recently formed ophiolite must have provided the dominant heat source for metamorphism, and frictional heating is unlikely to have supplemented this to any great extent (Malpas 1979).

\section{The Dortila ophlollte}

The Donqiao ophiolite of northem Tibet lies along the Bangong - Naijiang suture (BNS), which separates the Lhasa and Qiangtang terranes of southwestern China (Fig. 1). A Jurassic age has been inferred for the complex from radiolaria in associated cherts. In addition, the ophiolite is overlain unconformably by shallow-water limestones and terrestrial sandstones of earliest Cretaceous age, which were deposited after its emplacement. These data suggest that the ophiolite was obducted in latest Jurassic to earliest Cretaceous time, about $140 \mathrm{Ma}$ ( $\mathrm{F}$. Wang and Tang 1984). The ophiolite is considered to have formed in a suprasubduction zone environment (Girardeau et al. 1984, 1985, 1986), and like many other ophiolites formed in this way, was apparently emplaced very soon after its genesis.

Metamorphic rocks are closely associated with the dia bases and peridotites of the Donqiao ophiolite. Girardeats et al. (1986) reported the chemical compositions of amphboles from foliated amphibolites beneath the diabase com- 
olex as well as amphiboles in the diabases of the nearby Baila massif. Beneath the harzburgites of the Donqiao massif, metamorphic rocks range from amphibolites to greenschist facies in an inyerted metamorphic sequence not unthe that of the classic Newfoundland localities (Malpas 1970: Jamieson 1980).

At Donqiao, blocks of pillow lava, cumulate rocks, and mantle peridotites occur in a belt tectonically bounded by Jurassic phyllites and sandstones to the north and by limestones to the south (Girardeau et al. 1984). The Donqiao massif itself is a block of harzburgite that extends approximately $18 \mathrm{~km}$ along the strike of the belt and ranges: from 3 to 5 kn in width. The Early Cretaceous shallow-water and terrestral deposits that unconformably overlie the massif consist of conglomerates at the base containing chromites derved from the ultramafic massif, succeeded by sandstones and limestones.

The harzburgites are coarse-grained rocks with granular to porphyroclastic textures, composed of olivine and orthopyroxene with small amounts of clinopyroxene and chromite. pods and lenses of dunite, many hosting small chromitite bodies, and narrow pyroxenite dykes are also present.

The metamorphic rocks form a narrow ridge that extends for approximately $2 \mathrm{~km}$ along the northem margin of the massif (Fig. 1). They are typically dark grey to greenish grey and exhibit prominent banding. The metamorphic sequence is nowhere more than $8-9 \mathrm{~m}$ wide and shows considerable Vartation in metamorphic grade over this distance. Immediately adjacent to the ophiolite is a banded pyroxene homfels composed of light green diopside crystals in a matrix of brown, microcrystalline material. In many samples the diopside occurs as bands of subhedral crystals up to $1 \mathrm{~mm}$ in limension, but in rare cases may form relatively large porphyroblats $(2-3 \mathrm{~mm})$. A few centimetres from the contact with the hamburgite, the diopside is partially retrograded to brown hornblende. Replacement appears to be confined to narrow zoncs, resulting in a banded rock with pale green layers rich in diopside and darker brown layers composed dominantly of brown amphibole. In the diopside-rich layers, brown amphtole is seen replacing the pyroxene along crytal margins and filling interstices between the crystals, apparently a retrograde effect. Garnet has been found in one sample (DM5) at $45 \mathrm{~cm}$ from the contact. Moving away from the peridotites, replacement of pyroxene by amphibole hereases, and the rocks become amphibole mylonites in which a few narrow bands of granular diopside and rare diopside porphyroblasts are preserved. The brown hornhende forms small, generally equidimensional grains, between 0.2 and $0.4 \mathrm{~mm}$ in size, which show little preferred orientation. although the rock has an overall banded appearance. Af a distance of approximately $1 \mathrm{~m}$ from the contact, no diopsite is present and small amounts of brown biotite coexist with the brown hormblende, neither of which shows a promifient lineation. At approximately $1.5 \mathrm{~m}$ from the contact, brown horwblende is replaced by green homblende, and by $2 \mathrm{n}$, the amphibolites are dominated by green homblende with small amounts of albite and apatite. The rocks no longer display the banded appearance so prevalent higher up, athough the amphibole is more acicular than the brown eney and displays a pronounced mineral lineation. Minor amutits of green chlorite rim some of the hornblende crystals.
Near the base of the aureole, $7-8 \mathrm{~m}$ from the contact with the peridotites, tight isoclinal folds are apparent. Here, the rocks are well-foliated quartz - mica schists in which relict protolith textures are still rarely preserved. In thin section, the hinges of folds are marked by concentrations of microcrystalline quartz. Fold limbs are highly sheared and attenuated. Sense of shear is clearly demonstrated by the development of $\mathrm{C}-\mathrm{S}$ fabrics and "fish structures." Relatively large $(>1 \mathrm{~mm}$ ) angular grains may represent relict crystals of rock fragments in the protolith, which at this level appear to have been volcanogenic sedimentary rocks. Such rocks are exposed in outerops farther to the north, but in the immediate vicinity of the ophiolite are covered by Quaternary alluvim.

All of the rocks of the aureole are cut by narrow $(1-3 \mathrm{~nm}$ wide) veinlets of zoisite and minor calcite. These are completely undeformed and typically cut the fabric of the host rocks at high angles. They prestmably formed under brittle deformation conditions during thermal relaxation of the metamorphic rocks after thrusting and exhumation.

\section{Mineralogy}

Microprobe analyses of amphiboles, pyroxenes, plagioclase, mica, garnet, and zoisite from metamorphic rocks are presented in Table 1.

Amphiboles are collectively magnesiohomblendes (Fig. 2), but the brown amphboles are markedly more $T i$ rich than the green varieties. In the presence of sphene, imenite, and magnetite, this equates with higher temperatures of metamorphism (Leake 1965, Raase 1974). The amphiboles cluster around the tremolite-actinolite - Al-pargasite join (Fig. 3), corresponding to a high-temperature rather than a high-pressure metamorphic trend. Clmopyroxene occurs only in the 2.5 m of amphibolites closest to the peridotites. All of the pyroxenes analyzed are diopside, with very little chemical variation. Plagiodases from greenschist facies metasedimentary rocks are clearly albitic in composition. In the amphibolites, the plagtoclases are of intermediate composition. Garnet has only been recognized in one sample of amphibolite (DM5), collected $45 \mathrm{~cm}$ from the contact with the peridotites. It has an average composition of $\mathrm{Gr}_{66} \mathrm{Al}_{32} \mathrm{Py}_{1} \mathrm{Sp}_{1}$, suggesting the possibility of some retrogression to hydrogrossular, presumably as a result of rodingitization.

The mineral paragenesis, which occurs over a distance of $8 \mathrm{~m}$, is similar to that described from the aureoles of the Bay of Islands ophiolite in western Newfondiand (Malpas et al. 1973; Malpas 1979) and Semail ophiolite of Oman (Searle and Malpas 1980), and suggests increasing temperatures of metamorphism towards the harzburgite contact (Jameson 1980). However, at first glance, the metamorphic gradient of the Donqiao aureole appears steeper than that of the Bay of Islands. Prograde homblende and intermediate plagioclase suggest that minimum temperatures of at least $475^{\circ} \mathrm{C}$ were achieved. The lack of prograde chlorite close to the peridotite contact suggests temperatures in excess of $550^{\circ} \mathrm{C}$ (Apted and Liou 1983). The occurrence of diopsidic clinopyroxene near the contact suggests that here temperatures might have reached as high as in the granulite facies, in excess of $750^{\circ} \mathrm{C}$, assuming the oxygen tugacity was equivalent to the quartz- 
Table 1. Representative andyses of metamorphic minerals from the aureole of the Dongiao massif.

\begin{tabular}{|c|c|c|c|c|c|c|c|c|c|}
\hline $\begin{array}{l}\text { Sample: } \\
\text { Mineral: } \\
\text { Distance (m): }\end{array}$ & $\begin{array}{l}\text { DM1 } \\
\text { Amph E } \\
0.00\end{array}$ & $\begin{array}{c}\text { DE2 } \\
\text { Amph G } \\
1.00\end{array}$ & $\begin{array}{c}\text { DMl8 } \\
\text { Amp G } \\
7.00\end{array}$ & $\begin{array}{l}\text { DMI } \\
\text { Diop } \\
0.00\end{array}$ & $\begin{array}{l}\text { DN5 } \\
\text { Diop } \\
0.45\end{array}$ & $\begin{array}{c}\text { DNE } \\
\text { Ab } \\
7.00\end{array}$ & $\begin{array}{c}\text { DEI } \\
Z 0 \\
1.00\end{array}$ & $\begin{array}{l}\text { DM3 } \\
\text { Biot } \\
0.15\end{array}$ & $\begin{array}{l}\text { DMS } \\
\text { Gar } \\
0.45\end{array}$ \\
\hline $\mathrm{SiO}_{2}$ & 45.87 & 47.17 & 47.23 & 52.30 & 52.69 & 69.15 & 43.58 & 43.08 & 36.73 \\
\hline $\mathrm{TiO}_{2}$ & 1.66 & 0.89 & 0.62 & 0.28 & 0.19 & 0.03 & 0.00 & 2.54 & 1.15 \\
\hline $\mathrm{Al}_{2} \mathrm{O}_{3}$ & 9.62 & 8.27 & 9.70 & 1.77 & 1.34 & 20.22 & 23.52 & 10.21 & 7.68 \\
\hline $\mathrm{FeO}$ & 13.47 & 16.20 & 14.97 & 9.95 & 10.34 & 0.23 & 0.54 & 15.55 & 19.92 \\
\hline $\mathrm{MnO}$ & 0.23 & 0.27 & 0.28 & 0.24 & 0.29 & 0.02 & 0.05 & 0.18 & 0.41 \\
\hline Mgo & 13.95 & 12.44 & 13.47 & 14.47 & 13.33 & 0.08 & 0.20 & 12.04 & 0.23 \\
\hline $\mathrm{CaO}$ & 11.09 & 12.13 & 10.84 & 21.27 & 21.84 & $0 . \frac{4}{6} \frac{4}{6}$ & 25.68 & 11.37 & 32.18 \\
\hline $\mathrm{Na}_{2} \mathrm{O}$ & 1.80 & 1.11 & 1.33 & 0.46 & 0.76 & 10.16 & 0.10 & 1.85 & 0.09 \\
\hline $\mathrm{K}_{2} \mathrm{O}$ & 0.46 & 0.14 & 0.10 & 0.01 & 0.01 & 0.18 & 0.03 & 0.87 & 0.00 \\
\hline $\mathrm{P}_{2}^{2} \mathrm{O}_{5}$ & 0.08 & 0.14 & 0.04 & 0.02 & 0.00 & 0.15 & 0.12 & 0.00 & 0.00 \\
\hline Total & 98.23 & 98.76 & 98.58 & 100.75 & 100.79 & 100.65 & 93.82 & 97.68 & 98.40 \\
\hline$\$ i$ & 6.98 & 7.20 & 7.15 & 1.94 & 1.96 & 2.98 & 3.46 & 6.16 & 6.26 \\
\hline $\mathrm{TH}$ & 0.19 & 0.10 & 0.07 & 0.00 & 0.00 & 0.00 & 0.00 & 0.27 & 0.14 \\
\hline$A_{1}{ }^{N V}$ & 1.01 & 0.79 & 0.84 & 0.05 & 0.03 & 0.01 & 0.00 & 0.00 & 0.00 \\
\hline $\mathrm{Al}^{\mathrm{VI}}$ & 0.71 & 0.69 & 0.88 & 0.02 & 0.02 & 1.01 & 2.20 & 1.72 & 1.54 \\
\hline $\mathrm{Fe}$ & 1.71 & 2.07 & 1.89 & 0.30 & 0.32 & 0.00 & 0.03 & 1.86 & 2.84 \\
\hline$M n$ & 0.03 & 0.03 & 0.03 & 0.00 & 0.00 & 0.00 & 0.00 & 0.02 & 0.05 \\
\hline $\mathrm{Mg}$ & 3.16 & 2.83 & 3.04 & 0.80 & 0.74 & 0.00 & 0.02 & 2.56 & 0.05 \\
\hline $\mathrm{Ca}$ & 1.81 & 1.98 & 1.75 & 0.84 & 0.87 & 0.02 & 2.18 & 1.74 & 5.88 \\
\hline $\mathbb{N a}$ & 0.53 & 0.32 & 0.39 & 0.03 & 0.05 & 0.85 & 0.01 & 0.51 & 0.02 \\
\hline $\mathrm{K}$ & 0.09 & 0.02 & 0.01 & 0.00 & 0.00 & 0.00 & 0.00 & 0.15 & 0.00 \\
\hline P & 0.01 & 0.03 & 0.00 & 0.00 & 0.00 & 0.00 & 0.01 & 0.00 & 0.00 \\
\hline Sum & 16.26 & 16.10 & 16.10 & 4.02 & 4.02 & 4.92 & 7.94 & 15.03 & 16.82 \\
\hline No. of $\mathrm{O}$ & 24 & 24 & 20 & 6 & 6 & 8 & 12.5 & 22 & 24 \\
\hline
\end{tabular}

Notes: Amph B, brown amphibole; $\mathrm{O}$, green amphibole; Diop, diopside; Ab, albite; Zo, zoisite; Biot, biotie; Gar, gamet.

Fig. 2. Chemical classification of the amphiboles from the aureole of the Donqiao massif, Hbl, homblende; "rsch, tschermakite.

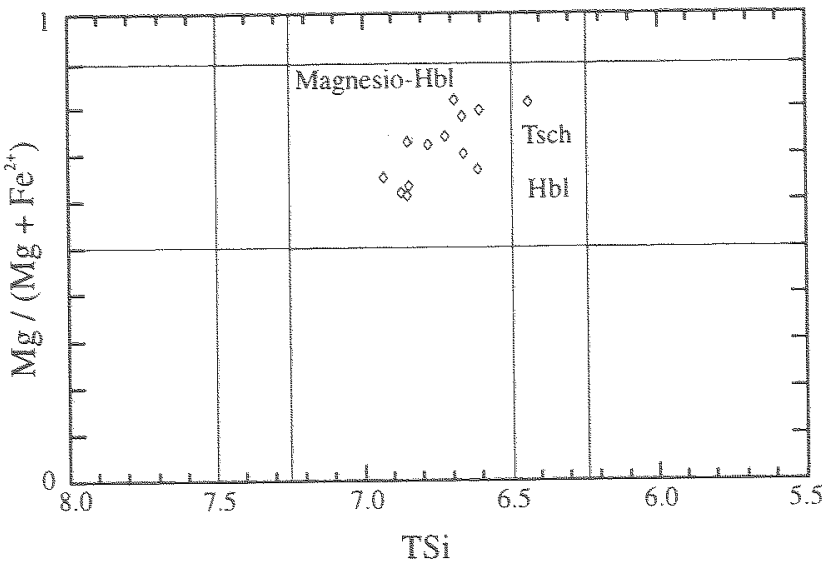

fayalite-magnetite buffer (Spear 1981). However, no orthopyroxene such as in the New foundland examples, has been found and it is thus improper to call the rocks granulites.

Because there are no aluminosicates and the mineral assemblage shows high variance, meaning ul themobarometry is dificul. Following the proneer expermental work of Rahem and Green (1974, 1975), the distrbution of iron and magnesium in coexisting gamet and clinopyroxene has been used as a geothemoneter by varions authors (c.g. Ells and
Nig. 3. Composition of amphiboles from the Dongiao metamorthic aureole in relation to high-temperature and high-pressure metamorphic trends.

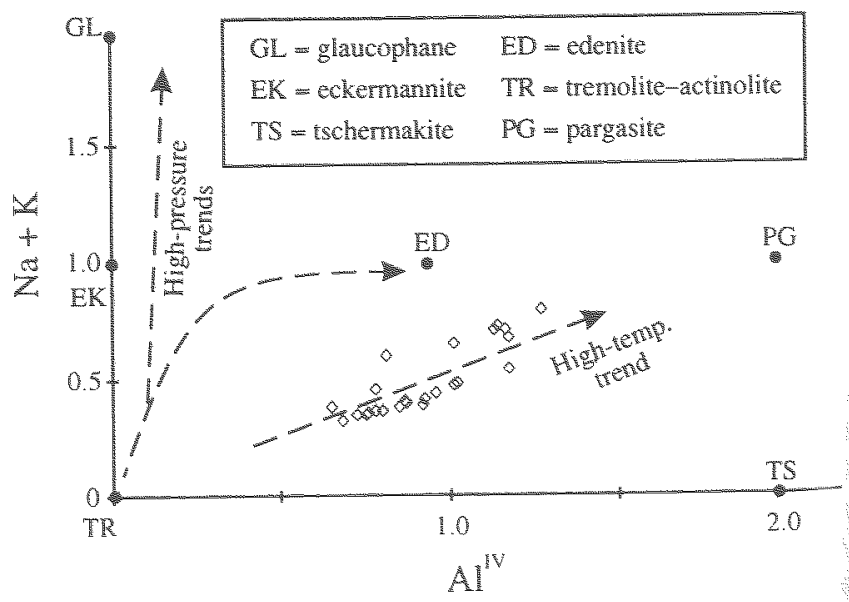

Green 1979; Graham and Powell 1984; Pattison and Newton 1988; T.H. Green and Adam 1991). The distribution coeft. cient $K_{\mathrm{D}}=(\mathrm{FeO} / \mathrm{MgO})_{\mathrm{gar}} /(\mathrm{FeO} / \mathrm{MgO})_{\mathrm{cpx}}$ was originally thought to decrease whin increasing temperature and be rela tively insensitive to changes in chemistry reflected in minor components of the pyroxene or gamet solid solutions. Hov. ever, the recent review by Beman et al. (1995) shows that $Y_{D}$ values depend on pressure and Ca content of garnet, $a^{s}$ 
Well as on temperature. An additional difficulty with using microprobe analyses is the estimation of actual $\mathrm{Fe}_{2} \mathrm{O}_{3} / \mathrm{FeO}$ ratios. If the rare Donqiao gamets are calculated as hydrogrossular, then $K_{\mathrm{D}}$ values indicate a temperature in the range of $280^{\circ} \mathrm{C}$ at $45 \mathrm{~cm}$ from the contact. Even applying all of the attendant caveats (Searle and Malpas 1982), this seems low for a garnet amphibolite produced at approximately 4 kar (400 MPa) pressure (D.H. Green and Ringwood 1967), and confirms that the garnet and clinopyroxene are no longer in equilibrium as a result of retrogression. Indeed, given that thermobarometry using garnet and elinopytoxenehomblende is so dependent on Ca content of the gamet, little sense can be made using the compositions here, which are so deanly a result of rodingitic alteration. Previous estimates of metamorphic temperatures for similar, unaltered assemblages from the Semail ophiolite of Onan are of the order of $800^{\circ} \mathrm{C}$ (Searle and Malpas 1980 ; Ghent and Stout 1981).

\section{$40 \mathrm{Ar}^{39} \mathrm{Ar}$ geochronology}

Two amphibole separates (DE1 and DE2) from the aurcole have been analyzed for argon isotopes. The samples were laken rom 1 and $2 \mathrm{~m}$ from the contact respectively and localities are shown in Fig. 1. The samples were irradiated in the MeMaster University nuclear reactor and argon isotopic analyses were undertaken using a VG 3600 mass spectrometer coupled to an intemal tantalum resistance fumace of the double-vacium type. Homblende MMhb-1, with an assumed age of $520 \pm 2 \mathrm{Ma}$ (Samson and Alexander 1987), was used as a standard for all analyses. Other experimental procedures follow those described by Muecke et al. (1988). Errors equted are the $2 \sigma$ analytical uncertainties; the estimated error in the irradiation parameter, $J$, is included, but no allowance is made for uncertainty in the age of the standard or in the valies of the decay constants.

Both samples yield relatively discordant age spectra and variable ${ }^{37} \mathrm{Ar} /{ }^{39} \mathrm{Ar}$ ( (proportional to $\mathrm{Ca} / \mathrm{K}$ ). Initial gas, especially in the case of DE1, is characterized by low ${ }^{39} \mathrm{Ar} /{ }^{39} \mathrm{Ar}$ ratios and low, ca. 80-90 Ma, ages. The final approximately $50 \%$ of gas released from both samples gave more consisient ages (180 $13 \mathrm{Ma}$ for DE1; $175 \pm 3 \mathrm{Ma}$ for DE2), along with higher ${ }^{37} \mathrm{Ar} /{ }^{39} \mathrm{Ar}$ ratios (Fig. 4 ).

\section{Discussion}

In many ways, the dynamothermal aureole of the Donciao ophiolite is not unlike occurrences elsewhere in the world. In all of these, however, a major question is why there are no high-pressure netamorphic minerals. If indeed the complexes were produced during subduction, then blueschist focies minerals such as lawsonite and glaucophane might nimnally be expected. Their absence must relate to the depth and icmperature of metamorphism and suggests a relatively shallow dipping subduction zone and high heat flow Such conditions might be associated with oblique subduction or subduction "rollback," which facilitates ophiolite genesis by chprasubiuction spreading (Fig. 5). It is to be remarked that 1t of the previously described occurrences of dynamotherrnof atreoles appear to be associated with suprasubduction Wone ophiolites (references cited above). The subduction rolfack model would certainly favour crustal extension and bathing inmediately above the subduction zone, and high
Fig. $4{ }^{40} \mathrm{Ar} /{ }^{39} \mathrm{Ar}$ spectra of the homblendes (DEI and DE2) from the aureole of the Donqia massif.
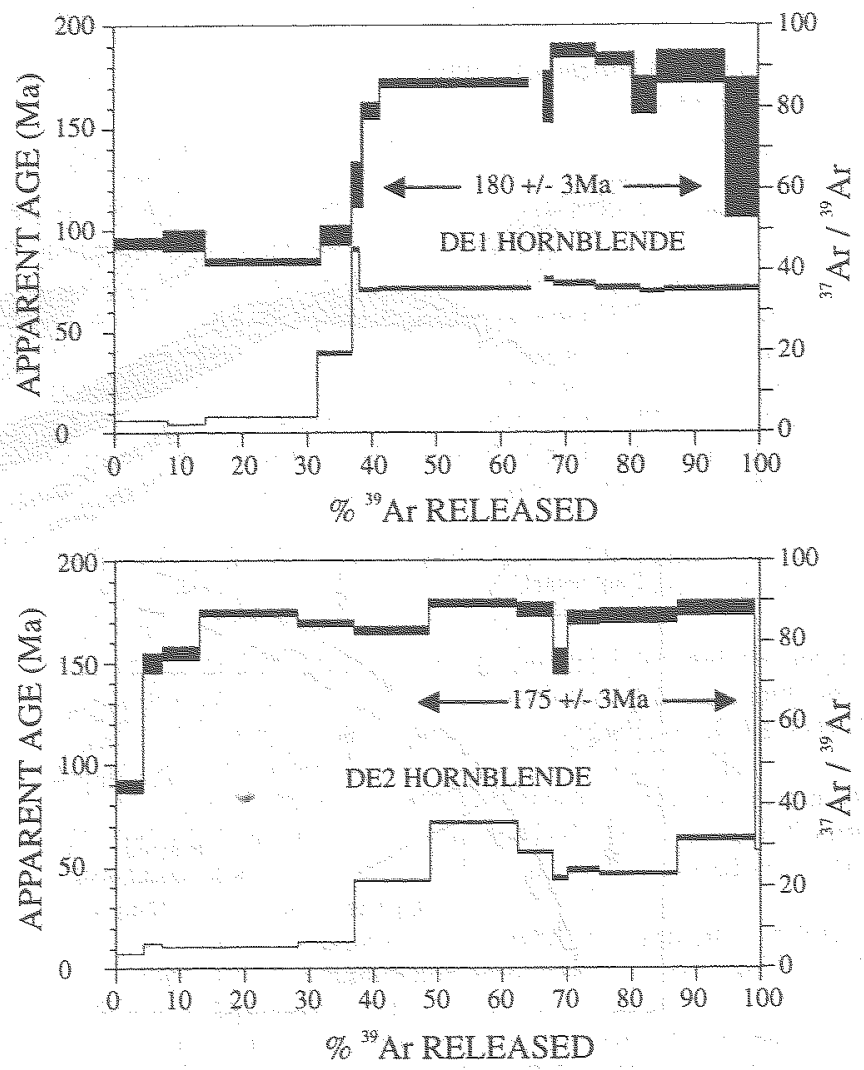

heat flow is to be expected in an area of magmatic activity. The process of subsequent exhumation of the subcreted metamorphic rocks is still not fully understood, but no doubt would be facilitated in a zone of crustal extension and mantle upwelling. This, however, remains an outstanding problem:

Compared with the dynamothermal aureoles of the White Hills and Bay of Islands in Newfoundland, the Donqiao sequence is considerably thinner. It is unreasonable that this is simply due to a higher thermal gradient during metamorphism; rather, it is more likely a result of structural thinning of the metamorphic sequence during emplacement. Such reduction in the thickness of the complex may have taken place relatively early along the amphibolite-grade mylonite zones close to the present contact with the peridotites.

Ages of radiolarites and fossilferous fiysch deposits directly associated with the Donqiao ophiolite indicate that it was formed in the Jurassic (F. Wang and Tang 1984). On the basis of unconformably overlying Early Cretaceous sedimentary rocks, obduction is inferred to have occurred in latest Jurassic - earliest Cretaceous time, ca. $140 \mathrm{Ma}$ (Girardeau et al. 1984, 1985, 1986; F. Wang and Tang 1984; X. Wang et al. 1984). However, the new Ar-Ar ages presented here provide a $175 \mathrm{Ma}$ displacement age for the opholite. This Middle Jurassic age correlates well with a U-Pb metamorphic age of $171+6 \mathrm{Ma}$ for zircon and sphene from a K-feldspar - biotite - chlorite - epidote gneiss at Anduo, some $50 \mathrm{~km}$ east of Donqiao (Xu et al. 1985), suggesting that both metamorphic sequiences were formed by the collision of the Lhasa and Qiantang terranes. The disparity in radiometric and stratigraphic ages of ophiolite obduction clearly indicates 
Mig. 5 . Model for the generation of the Donqia ophiolite and its dynamothermal aureole in a suprasubduction zone setting.

A

\section{Conthentringring}

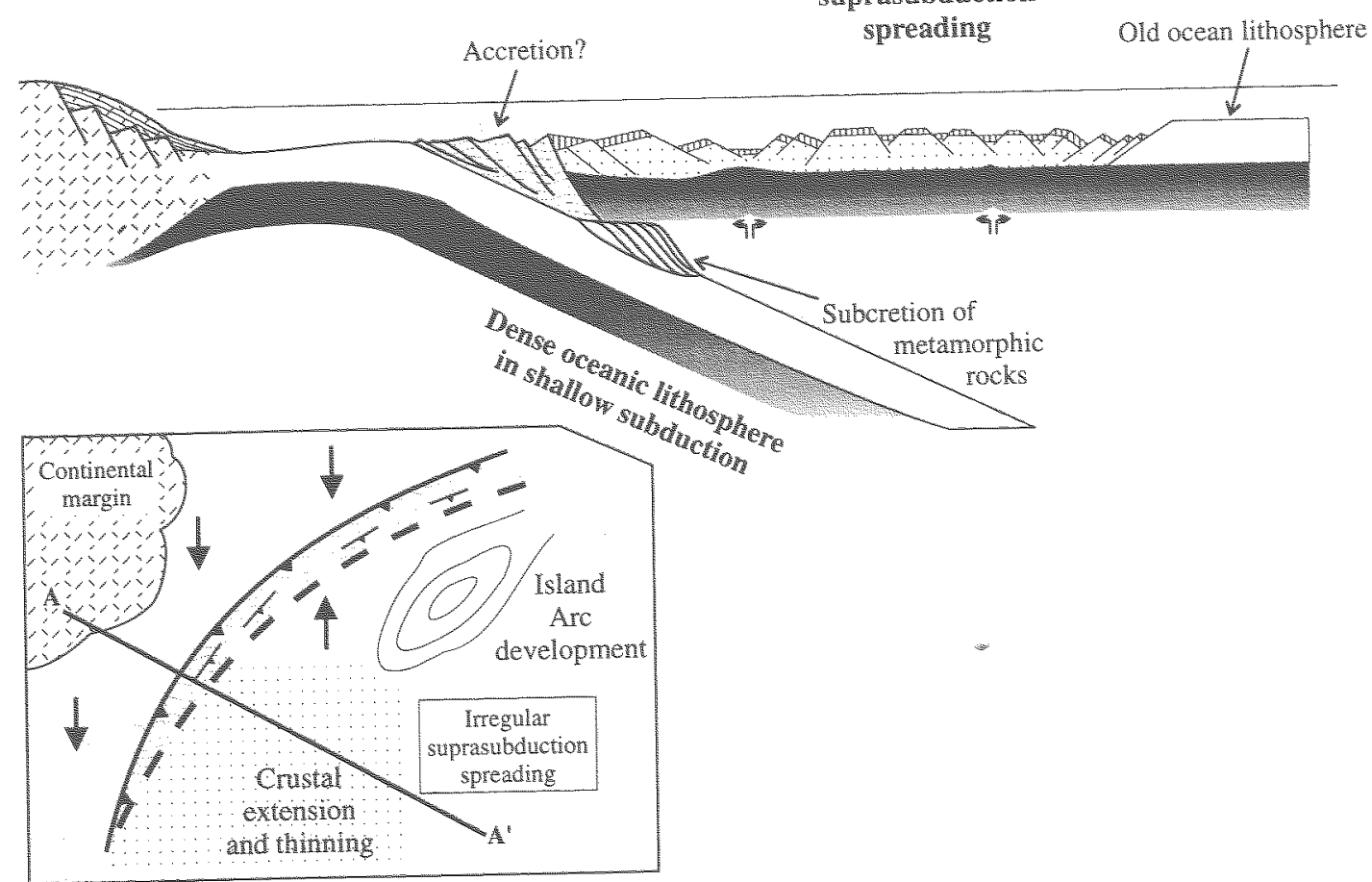

Irregular

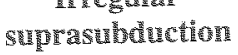

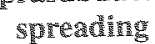

the importance of obtaining accurate isotopic ages with which to date the displacement event. The stratigraphic evidence simply provides the niminum age for find emplacement of the thrust slices.

Ar-Ar ages of other volcanic rocks (basalts, andesites, and dacites) in the Donqiao area range from 80 to $120 \mathrm{Ma}$ (Maluski et al. 1985, 1988 ; Coulon et al. 1986), much younger than the emplacement of the opholite and the collision between the wo terranes. These volcanic rocks must be related to intrablock tectonic events.

\section{He}

The investigation was supported by Natural Sciences and Engineening Research Council of Canada research grants to

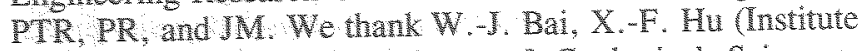
of Geology, Chinese Academy of Geological Soiences, Beijing, $G$. Davies (Vie University, The Netherlands), J. Guo (Thetan Geologlcal Survey), and $\mathrm{O}$. Suhr (Kom University, Gemany) for support in the feld in 1994 . We are grateful to $\mathrm{K}$. Taylor for assistance whin the Ar-Ar analyses, R. Mackay whin electon microprobe andyses, and I. Brydie whth drating the diagrams.

\section{Raterences}

Apted, M. and Lou, M.G. 1983. Phase relations among greenschis ,ptiots amphbolste, and amphibohte in a basaltic sys-

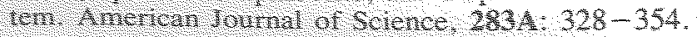

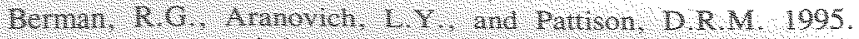

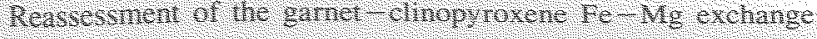

themometer: II. Thermodymamic analysis. Contributions to Mineralogy and Petrology, 1 is: $30-42$.

Coleman, R.G. 1977. Ophiolites: ancient ocean lithosphere? Springer-Venlag, New York.

Conlon, C., Maluski, H., Bolinger, C., and Wang, S. 1986. Mesozoic and Cenozoic volcanic rocks from central and south em Thet; ${ }^{39} \mathrm{Ar} /{ }^{10} \mathrm{Ar}$ dating, petrological characteristics and geodymamical significance. Earth and Planetary Science Leters, $79: 281-302$.

Dickey, J.S. 1970. Partial fusion products in alpine-type perido tites: Serrania de la Ronda and other examples. Mineralogicd Society of America, Special Paper 3, pp. 33-49.

Elis, D.J., and Green, D.H. 1979. An experimental study of the effect of Ca upon gamet-chnopyroxene Fe-Mg exchange equilibria. Contributions to Mineralogy and Petrology, 7 $13-22$.

Ghent, E.D., and Stout, M.2. 1981 . Metamorphism at the base of the Semail Ophiolite, southeastern Oman Mountains. Joumel of Geophysical Research, $86: 2557-2572$.

Ginardean, J., Marcoux, J., Allegre, C.J., Bassonllet, I.P. Tang, Y., Xiao, X., Zao, Y., and Wang, X. 1984 . Tectont environment and geodynamic significance of the Neo Cimmerian Donqiao ophioite, Bangong - Nu Jiang suture zone, Tibet, China, Nature (London), 30\%:27-31.

Girardeau, J., Marcoux, J., Pourcade, E., Bassoulet, J.P., and Tang, Y. 1985. The Xanka ultramafic rocks, Central Thet China: tectonic erviroment and geodynamic significanco. Geology, 13: $330-333$.

Giratean, I., Mercier, I.C.C., and Tang, Y. 1986. Petrology of the Donqiao-Xanxi opholte (North Thet, China): evidere for its formation in a suprasubduction zone enviromint Ofioliti, 11 : $235-262$.

Graham, C.M., and Powell, R. 1984, A gamet-homblent geothemoneter: calibration, tesing, and application wo the 
Pelon Schist, southern Calfomia. Jounal of Metumorohic Goology, $2: 13-31$.

Cren, D.H. 1964. The metamorphic anreole of the peridotite at the Urard, Comwall. Joumal of perrology, $5,543-563$

Great, D.H. and Ringwood, A.E. 1967. The stability fields of alwhinous pyroxene peridotite and ganet peridotite and their fevance in upper mante strucure. Earth and Planetary Science Coters, 3: $151-160$.

Gren, TH., and Adam, Y. 1991. Assessment of the gametChopyroxene Fe-Mg exchange themoneter using new experInenal data. Journal of Metamorphic Geology, 9: $341-347$.

Jimeson, R.A. 1980. Ophiolite emplacement as recorded in the Whanothermal aureole of the St. Anthony complex, worthrostern Newoundand. 7 : Opholites, Procedings of the Interhetonal Opholite Synposim, Cyprus, 1979. Edted by A. Panaytotou.

1.tamata, S 1968. Zonality in contact metamomhic rocks around the ulramafic nass of $\mathrm{Brezovica}$ (Serbia, Yugoslavia). Procedngs, Thtemational Geological Congress, Prague, part. Di. $197-207$.

Leake, $\mathrm{B}, \mathrm{E}$. 1965. The relationship between composition of calchens amphibole and grade of metamorihin. he Controls di netanorphisn. Edhed by W. S. Pitcher and D. Finn. OHver and bov, Ediburgh, pp. $299-318$.

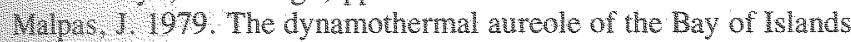
opholte swite. Candian Jounal of Earth Sciences, 16: 20862101.

Malras, I, and Stevens, R.K. 1977. The origin and emplacement of he opholite suite with examples from westem Newlown-

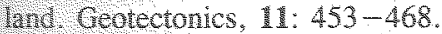

Malpas. Y, Stevens, R.K., and Strong, D.F. 1973. Amphibolite assocated wh Newfoundand ophohte, its classification and tectonic significance. Geology, $1: 45-47$

Wapas. J., Xenophontos, C., and Willoms, D. 1992, The Ayia Var wh Fomation of SW Cyprus: a product of complex collisionil tectonics. Tectonophysics, 212: $193-211$.

Malusl, I Conlon, C., and Wang, S. 1985. ${ }^{39} \mathrm{Ar} /{ }^{40} \mathrm{Ar}$ radiometric ages of orogenic volcanics trom central and norhern Tbet. Terra Cognit, 5: 279 [Abstract.

Walusk. 1. Matte, P., and Brund, M. 1988. Ar-Ar dating of meartorite and putonic events in the norh and high Thualuan bels (somhern Tibet - China). Tectonics, 7: $299-$ 326
Muecke, G.K. Elas, P., and Reynolds, P.H. 1988. Hercyntan Aleghanan overprinting of an Acadan terrane: Ar/Ar studies in the Meguma zone, Nova Scotia, Canada. Chemical Geology, 3. $153-167$.

Pattison, D.R.M., and Newton, R.C. 1988. Reversed experimental calbration of the gamet-dinopyroxens: $\mathrm{Kd}(\mathrm{Fe}-\mathrm{Mg}$ ) exchange themoneter. Contributions to Mneralogy and Petrology, 10 i: $87-103$.

Raase, P. 1974. Al and Ti contents of homblendes; indicators of temperatre and pressure of reglonal metamophism. Contribu tions to Mineralogy and Petrology, $48: 231-236$.

Raheim, A., and Creen, D.H. 1974. Experimental determination of the pressure and temperature dependence of the Fe-Mg partition coefficient for co-exising gamet and chopyroxene. Contributions to Mneralogy and Petrology, $48,179-203$.

Rahein, A., and Green, D.H. 1975. $P$, T paths of natural eclogites during metamorhism a record of subduction. Lithos, $8: 317-$ 328.

Samson, S.D., and Alexander, E.C., J. 1987. Calbration of the interlaboratory Ar/Ar dating standard, Mmbbl, Chemical Geology, $66: 27-34$

Searle, M.P., and Malpas, I. 1980 . The strucure and metamorphism of rocks beneath the Semail opholite of oman, and their significance in opholite obducton Transactions of the Royal Society of Edwburh Eath Senence, $71+213-228$.

Searle, M.P, and Malpas 1398 , Petrochemistry and origin of sub-ophidte metamophe and related rocks in the Oman Mounans. Jourtal of the Geological Soctety (Lonoon), 139 : $235-248$

Spear, F., 1981 . An expermenta sudy of horbulende stability and compostronal varbinty in anphibolte. American Joumal of Science, $281: 697-734$

Wang, F., and Tang, Y.1984. Primary andysis of tectonic environment of the ophiolte in worhern Tbet. Hmalaya Geology, 墨: 99-113. Ini Chinese.]

Wang, $X$, Bato, $P$, and Zheng, $H$. 1984. A teconically dismembered ophiolte in the Lake area of nothern Thet and its geochemistry. Himulaya Geology. M: 115-143. [n Chinese.]

$\mathrm{Xu}, \mathrm{R}$, Scharer, $\mathrm{U}$, and Allegre, C., 1985. Magmatism and metamorphism in the Lhasa block (Tbet): a geochronological study. Yournal of Geology, 93: $41-57$. 